\title{
National identity, social legacy and Qatar 2022: the cultural ramifications of FIFA's first Arab World Cup
}

\section{Thomas Ross Griffin}

To cite this article: Thomas Ross Griffin (2019) National identity, social legacy and Qatar 2022: the cultural ramifications of FIFA's first Arab World Cup, Soccer \& Society, 20:7-8, 1000-1013, DOI: 10.1080/14660970.2019.1680499

To link to this article: https://doi.org/10.1080/14660970.2019.1680499

\section{(c) 2019 The Author(s). Published by Informa UK Limited, trading as Taylor \& Francis} Group.

\section{Published online: 21 Oct 2019.}

Submit your article to this journal $₫$
Џll Article views: 1349

Q View related articles $\square$

View Crossmark data $\asymp$ 


\title{
National identity, social legacy and Qatar 2022: the cultural ramifications of FIFA's first Arab World Cup
}

\author{
Thomas Ross Griffin (iD)
}

Department of English Literature and Linguistics, Qatar University, Doha, Qatar

\begin{abstract}
This article argues that the decision to award Qatar the World Cup in 2022 will have a lasting impact on the Gulf state. I suggest that hosting the 2022 World Cup is a central part of Qatar's strategy to announce itself as a legitimate actor on the world stage, one unique amongst other Muslim and Arab nations. I contend that the World Cup is a vital part of this process because it allows Qatar a space that permits the emirate to address specific issues within its society in a manner which coexists with, rather than surrendering to, external values and norms. The article concludes by arguing that if Qatar 2022 is to justify FIFA's decision to cross one of the last civilizational bridges left in global sport, it will have to demonstrate that the image and reform it presents to the rest of the world are genuine and lasting.
\end{abstract}

\section{Introduction}

In their paper, 'Power and resistance in the governance of world football', John Sugden and Alan Tomlinson discuss the extent to which FIFA can be viewed as a transnational entity that can be used as a hegemonic counterbalance by developing nations with a history of colonialism. Sugden and Tomlinson correctly caution against such an interpretation of soccer's world governing body when they argue that soccer is in its essence a distinctly European game and that 'by playing international football, countries ... are confirming a social and political map imposed by the First World'. ${ }^{1}$ This article attempts to expand upon the ideas suggested by Sugden and Tomlinson by examining the historical significance for Qatar of hosting the World Cup. The determination of FIFA to traverse one of the last civilizational bridges left in global sport, the hosting of a World Cup, in an Arab and Muslim country suggests that these colonial boundaries are not the sacred spaces they once were. FIFA's decision indicates a growing challenge to the sanctity of the Old World boundaries and a historic opportunity for the Gulf state to declare an identity for itself bereft of longstanding Orientalist stereotype that will alter the global perception of the greater Arab World. ${ }^{2}$

\section{Literature review}

This article supplements the existing literature on sport in Qatar by revisiting Mahfoud Amara's works on the complicated relationship between sport and identity within the Arab world ${ }^{3}$ in the context of the current Gulf Cooperation Council (GCC) crisis whereby longstanding tensions have erupted into a complete cessation of relations between the emirate and regional rivals Saudi Arabia, 
UAE and Bahrain. The article argues that Qatar's desire to host the 2022 World Cup is closely linked to the wish to assert a new identity that challenges Orientalist stereotype surrounding the emirate while also identifying Qatar as intrinsically different from its regional partners. Much of the current academic research on the 2022 World Cup, across a multitude of disciplines, has focussed on two primary areas. The first of which is a study of the Gulf state's successful bid as a demonstration of Qatar's use of soft power to announce itself on the world stage as a legitimate nation state. ${ }^{4}$ The second examines the negative consequences of the emirate's victory in the bidding contest in $2010 .^{5}$ While these critics have been adept in highlighting the many pitfalls Qatar has encountered after being named as host, this article focuses more so on how the Gulf state has since attempted to address these concerns mooted by the international media. Other research relevant to this project examines how Sports Mega-Events (SMEs) are won and the opportunities and potential pitfalls such events purport to offer to their hosts thereafter. ${ }^{6}$ While the latter articles provide key insight into the efficacy of soft power in attempting to win the rights to host an SME, and the socio-economic consequences for the host once it has finished, Qatar and its World Cup are only ever tangentially, if at all, the focus of each. In recent years, there has been a significant increase in the number of comprehensive book-length studies on the emirate by Fromherz, Gray, Kamrava, Ulrichsen and Roberts. ${ }^{7}$ Each presents a fascinating study of Qatar, discussing to varying degrees the cultural nuances of Qatari society, including its ability to exert levels of what Joseph Nye defined as hard and soft power, and the nation's desire to brand itself to a global audience. However, due to Qatar's rapidly developing society, particularly in relation to the treatment of migrant workers, the participation of women in sport, and the escalation of tensions between Qatar and its GCC counterparts, the circumstances they describe to underpin many of the valid arguments they raise have changed. This article intends to address this lacuna by examining the potential for historical change within Qatari society prompted by the 2022 tournament.

\section{A new image of Qatar}

For generations, Qatar was a nation overshadowed by its oil-rich neighbours; however, technical advancements in the extraction of liquefied natural gas throughout the latter stages of the twentieth century have transformed Qatar into the region's (and the world's) wealthiest state. This change in status is reflected in a multitude of ways, but none more so eye-catching than the manner in which the emirate has begun to compete for the right to host some world's largest SMEs. Maurice Roche defines SMEs as 'large-scale, cultural (including commercial and sporting) events, which have a dramatic character, mass popular appeal and international significance'. ${ }^{8}$ It is generally agreed that only two sporting events fit this description: the Olympic Games and FIFA's World Cup. This approach bore meaningful fruit for Qatar for the first time on the 2 December 2010 when FIFA's Sepp Blatter announced Qatar as the host of the 2022 World Cup. As a young country with little World Cup tradition and massively lacking the infrastructure and amenities to handle a tournament of such magnitude at the time, what drove Qatar to compete to host these games?

One answer as to why an emerging nation would want to take up the challenge of hosting an SME is suggested by Scarlett Cornelissen. Rather than a celebration of sporting skill and endeavour, Cornelissen emphasizes that SMEs provide political influence often used by governmental bodies 'to foster loyalty or legitimacy, to project certain messages to the outside world, or to attain other wider policy objectives.' She goes on to highlight how the hosting of an SME can alter the perception of a developing country by questioning the validity of the stereotypes associated with the people who live there, "the archetypal other" against which the Western world juxtaposes and favourably evaluates itself. ${ }^{10}$ While Cornelissen's analysis focuses on the motivations underpinning the South African and Moroccan bids for the respective 2006 and 2010 World Cups, a close examination of Qatar's bid to host the tournament demonstrates a desire to achieve many of the same goals as their African counterparts. 


\section{Dispelling the image of the Arab 'Other'}

Foremost amongst these aims is the intention to challenge the colonial grand narratives long propagated as fact in the Cultural West that continue to perpetuate the stereotype of the Arab as the 'Other', an uncivilized, non-Christian, exotic and inferior entity whose social order exists in diametric opposition to the values and ideas of the West. The premise that such colonial grand narratives continue to exist into the twenty-first century might seem outlandish. However, one recent work on the representation of the 2022 World Cup highlights the predilection of both the Guardian and the Telegraph newspapers to recycle this 'us-and-them' model, describing Qatar and its people using a wide and varied idiom that would not be out of place in a Victorian Boys' Adventure novel. ${ }^{11}$ This practice has become more commonplace since it was announced that the World Cup was headed to the Middle East. Over the last decade or so, the Gulf state has been persistently reported as little more than a dusty outlier on the edge of the civilized world, one whose inhabitants, riven by double-dealing and corruption, clearly 'oppose the clarity, directness, and nobility of the Anglo-Saxon race'. ${ }^{12}$ Qatar's desert autocracy it would appear exists in sharp contrast to the liberal democracies of Western Europe, North America and similar societies within their sphere of influence. By their repeated use in the respected broadsheet press, these terms transform into apolitical representations of reality or 'grammars of exchange' as described by the postcolonial theorist Edward Said. ${ }^{13}$ As a result, positive reports of Qatar or its World Cup over the last eight years or so, particularly in the British broadsheet press, are rare commodities. ${ }^{14}$

\section{Qatar and the use of sport}

At the forefront of the country's aims in hosting the World Cup, from the onset of its bid, is the desire to present a positive image of Qatar and the Middle East by defying those stereotypes. However, disputing a common misconception is not the limit of Qatari ambition. I look to build upon the work of Lincoln Allison and Terry Monnington who state that an SME allows a host nation the occasion 'to sell themselves and enhance their image abroad'. ${ }^{15}$ I argue that Qatar seeks to use the tournament as a platform to announce itself as a legitimate actor on the world stage, and as a society that demonstrates universal values and norms, despite what are perceived as geographic and cultural differences by western nations. The basis of this claim lies in Mahfoud Amara's key argument in 'The Muslim World in the Global Sporting Arena' when he asserts that

... utilization of modern sport can be explained as a way for Gulf countries to build a new identity as an emerging model of a modern monarchy-state that has succeeded in finding the right balance between modern efficiency, symbolized in the efficient management of mega-sport projects, and the authenticity of Arab culture. $^{16}$

For Amara, sport is a particularly powerful tool for ex-colonial nations' intent on crafting a new national identity. Sport has long been used as a mechanism to exert imperial dominance over the colonial subject. Any form of success in that discipline enables the formerly colonized nation to successfully challenge the Orientalist version of themselves accepted as fact by large segments of the Cultural West.

It would appear that Qatar has heeded the words of academics such as Amara. From the late 1990s, up until the present day, sport has been an integral part of the strategy used to normalize Qatar's status in the global community. Over the past 20 years, international golf, tennis, cycling, motorsports and athletics events have all become mainstays of the Qatar sporting calendar, bringing the world's attention to the emirate's ability to successfully host sporting events. Although most are of a second or third-tier nature in their respective codes, comparatively large sums of prize money combined with a strategic scheduling during the worst of the Northern Hemisphere's winter months annually attract world-class athletes of both genders. Larger one-off events, such as the Asian Games in 2006, the World Handball Championships 
in 2015 and the World Cycling Championships in 2016, have also taken place in Doha, but all pale next to a soccer World Cup in terms of size and global significance. More than any other moment it has experienced in its young history, the World Cup provides Qatar with the occasion, the likelihood of which it may never have again, to demonstrate to the international community that despite some cultural differences, it shares the same views as any other nation on fair play, honesty and integrity so vital to every sport. Key to this process is that for the one million or so football fans anticipated for the tournament, their experience of the emirate will not be one of a society 'mired in religion, primitivity, and backwardness' but of 'a modern, progressive nation with a rich Islamic culture and heritage. ${ }^{17}$ To revert to Amara once more, 'sport can provide an avenue for the Muslim world and the West to negotiate their different identities beyond the usual national and culturally-fixed borders'. ${ }^{18}$

Hosting a tournament of such magnitude not only allows the emirate to challenge the stereotype but also demonstrates what Brannagan and Giulianotti describe as 'Qatar's professionalism and responsibility, as both an Eastern nation, and also as micro-state that is able to deliver on its goals' ${ }^{19}$ While critics such as Katrin Bromber and Birgit Krawietz do have reservations about the ability of these events to actually reflect the true culture of the host nation, they acknowledge that Qatar's persistent desire to present itself as a modern sports hub underlines its efforts to prove itself as a legitimate and fully fledged member of the international community, capable of competing with its peers on an international playing field. ${ }^{20}$ If viewed in postcolonial terms, just as the works of Chinua Achebe, Frantz Fanon and Ngugi'wa Thiong'o drew the attention of the literary world to the capabilities of the long-ignored African voice in the mid-twentieth century, sport was Qatar's medium of choice. As noted by Luis Silva, the staging of a Muhammed Ali fight in 1971, the exhibition match between Pele's Santos and Al-Ahli in 1973 and the hosting of the fourth Gulf Cup in 1976 reflected the emirate's use of sporting events and personalities to announce itself on the world stage as an independent, sovereign nation. Qatar's hosting of the World Cup has the capacity to reflect the capabilities of a region long overlooked. It is important to note that 'competing' in this context does not necessarily mean that Qatar has to progress deep into the latter stages of the World Cup itself in 2022. For a country of its size, its ability to win the rights to and then subsequently host the tournament will be a victory in itself. This argument is echoed by CM Hall when he says that 'the ability to attract events is often regarded as a performance indicator in its own right of the capacity of the city or region to compete'. ${ }^{21}$

\section{Reconfiguring Qatar}

That Qatar and its World Cup can be read as a synecdoche for the potential of the greater Arab world has been suggested on many occasions since the beginning of the bidding process. In a multitude of speeches and presentations advocating Qatar's suitability to host the finals, phrases such as 'Middle Eastern World Cup' and 'Arab World Cup' have been mentioned with similar frequency to 'Qatar's World Cup'. However, it is important to state that this does not infer an absolute homogeneity between Qatar and its GCC neighbours. One of the central arguments of this paper is that the emirate is using the World Cup to assert what Matthew Gray describes as a desire to show 'that Qatar is different from other Gulf states, not to mention Arab states' ${ }^{22}$ Such difference centres on the wish to be seen as a country 'responding to globalization actively and creatively, and reconfiguring Qatar socially ... to benefit from change'.

\section{The World Cup as Bhabha's 'Third Space'}

The nature of this reconfiguration is a significant point of discussion. A longstanding concern within Qatari society, one that its National Vision 2030 project seeks to address, is the preservation of a unique Qatari identity. The pillar dedicated to fulfilling this aim is to ensure that Qatari identity is not subsumed by globalization as much it is by other Arab nations. Theorists could make a case 
for saying that a national identity that embraces external values linked to the Cultural West is an example of postcolonial hybridity, one created within what Homi Bhabha describes as the 'Third Space of enunciation'. ${ }^{24}$ This view becomes more workable as a theoretical framework if the World Cup were viewed as a potential 'Third Space', a zone that Bhabha saw as marked by contradiction between colonizer and the colonized that enables a sense of the difference between cultures while also allowing aspects of hybridity. This latter idea gains traction when soccer is examined in terms of the sport's colonial past. Originally a method of inculcating within indigenous populations what were deemed to be the 'civilized qualities' of European society, soccer, in particular, remains a cultural artefact where the impact of the Old World on the New is still apparent. As Tomlinson and Sugden state, 'although some of the names might have changed, the shape and ethnic contents of the new nation-states that affiliated with FIFA were the same as those imposed by the old colonial powers a century earlier'. ${ }^{25}$ This becomes ever more evident in tournament soccer where oncecolonizer often meets once-colonized. In such instances, matches are used by some observers to highlight the commonality between nations and by others to insist upon an intrinsic difference. Most notable examples in past World Cups include France versus Senegal in Japan/South Korea 2002 and Republic of Ireland versus England in Italia 1990. A concern, however, for theorists whenever the controversial topic of hybridity is put to work is that acceptance of its existence in a postcolonial context often results in the colonial hierarchies of yesteryear being re-enacted. I argue that Qatar manages this concern within this 'Third Space' by attempting to coexist with global values, rather than surrendering to them. More clearly stated, rather than imposing an alien social framework upon its society and forcing its people to adapt, Qatar has sought to reconfigure and reform areas of its society in a manner that works within the traditions and practices of the Arab and Muslim world instead of altering them. The consequences of such a strategy not only ensure that the changes brought about by the 2022 World Cup will leave a lasting legacy for the residents of Qatar but also enable the emirate to reiterate the uniqueness of its society by demonstrating its capacity to enact global norms of behaviour within a Qatari context.

\section{The World Cup as a catalyst for change}

The most tangible example of such reconfiguration is in relation to the treatment of migrant workers. An investigation by the International Trade Union Confederation (ITUC) in 2013 prompted global outrage when it claimed that thousands of labourers from countries such as India, Bangladesh and Nepal were being forced to adhere to the kafala system of employment in order to build Qatar's World Cup infrastructure. The kafala system is a sponsorship mechanism in which unskilled labourers are sponsored by their employers to ensure their work visa remains valid. A longstanding practice in the Gulf region, it was originally intended as a means for a government to delegate the duty of care for an economic migrant to a private company or individual. However, it also has the potential to enable the abuse of those working within such a system. Although retracted a few weeks after its publication, the ITUC report, replete with reports of labourers working and living in infernal conditions, receiving minimal or no wages, and being prevented from returning to their home countries, quickly garnered the attention of Western media outlets.

\section{Qatar's labour landscape}

In response to a cacophony of calls from human rights watchdogs such as the International Labour Organization (ILO), ITUC and Amnesty International, Qatar began to reform its kafala system in December $2016 .{ }^{26}$ In the months that followed, a wide-ranging number of labour reform initiatives began to be implemented into law. These have included a minimum wage for all workers, electronic wage transfer systems and the creation of a government authority to issue residency permits and work visas, as well as oversee work contracts. These, and a bevy of other programmes relating to health, training and education, led the ITUC General Secretary, Sharan Burrows, one of Qatar's 
most strident critics, to recently laud the emirate as a role model for its neighbours in the region to imitate. ${ }^{27}$ Other indicators of this 'willingness' to adapt are suggested by the establishment of an ILO project office in Doha to oversee the implementation of wide-ranging changes relating to labour rights and working conditions in Qatar. ${ }^{28}$ To explain what is occurring in Qatar, on a deeper level, we must revert to Brannagan and Giulanotti once more: 'we see how global sporting forms act as vehicles for nation-state to construct or reshape specific brand identities and achieve certain foreign policy objectives'. ${ }^{29}$ Rather than ignoring the problem as several of its regional partners continue to do, Qatar has begun to open channels of communication to address the issues raised by key transnational human rights actors in a manner that mirrors that of the liberal democracies of the West. There is much work still left to be done to ensure the ongoing protection of migrant workers in Qatar, a point admitted by the Secretary General of the Supreme Council for Delivery and Legacy, Hassan Al-Thawadi, in an interview with The New York Times in October 2017.30 However, as these alterations to Qatar's labour landscape continue, it will represent a significant marker on the path towards restructuring the nation's identity on an international platform.

\section{The development of women's sport in Qatar}

The years that followed the declaration of Qatar's victory have also seen a number of significant changes occur in the area of women's sports in the Gulf state. Historically limited by what Knez et al. describe as 'religious and patriarchal constraint ${ }^{31}$ that Qatar was to be the host of the 2022 World Cup immediately resulted in an increased visibility in soccer across all levels, including the state of, or more accurately put, the paucity of the women's game in the emirate. ${ }^{32}$ However, given the foundation of a women's national team in 2010 and domestic soccer league in 2012, there is much evidence to suggest that the World Cup has acted as a catalyst towards gender, in addition to migrant labour, reforms. While Qatar is not unique amongst other Arab nations in establishing a women's national team and league, what does distinguish the emirate is how the athletes concerned have been endorsed by the royal family and embraced by the Qatari media. This is significant given that the physical body in sport is the source of the spectacle and the unremitting focus of the spectator; and sports clothing that is frequently tight or revealing has the potential to contravene traditional Islamic customs related to modesty and reputation. Yet royal endorsement, such as that offered to the Qatar Women's Sports Committee by HH Sheikha Mozah Bint Nasser, ensures that those who take part in the sporting activity are not cast as women wilfully disregarding social norms. ${ }^{33}$

Coverage in the local television and newspaper press has also been very positive in tone. Rather than portraying the players as encroaching upon what has traditionally always been a masculine space, the focus has instead been on other matters more important to the players. These include the benefits of sporting activity to the athlete, the support they have gotten from their families, their successes whilst adhering to the instruction of their faith and how they use their experiences in sport to teach their own children's key values, such as the importance of teamwork. The significance of this portrayal is that it demonstrates that these women can be athletes who at once uphold cultural and religious codes of behaviour and benefit the wider society. This historic cultural shift, whose inception I suggest began with the awarding of the men's World Cup in 2010, has quickly spread from soccer to other sports to reveal the signs of a lasting legacy for women's sport in Qatar in the wake of the tournament. Tangible indicators of this rapidly changing mindset abound. On a social level, these include the Supreme Committee announcement that the Education City World Cup stadium was to be the permanent home for the women's national team, the 'Hey' Ya Arab Women in Sport' photo exhibition aimed at encouraging Qatari girls to take an active interest in sport and the provision of female-only spaces throughout the country for women to exercise. ${ }^{34}$ These developments are complemented by a multitude of articles in the local media such as profile pieces of female athletes, published interviews emphasizing the importance of women's sports with Lolwa Al Marri, Chairperson of the Qatar Women's Sports Committee (QWSC) and televised coverage of 
women's domestic soccer games. ${ }^{35}$ As is the case with the treatment of migrant workers, there is still much to be done for Qatar to establish itself as a centre of excellence for sportswomen. The reality is that prior to the announcement of the World Cup's arrival, sport for women in Qatar was still something to be aspired to rather than actually engaged in on a regular basis. However, a sea change has begun. London 2012 saw Qatari sportswomen for the first time as the emirate sent three athletes to compete in shooting, swimming and sprinting events. At the most recent Asian Games in Jakarta in 2018, the number was $40 .{ }^{36}$ Unlike other Arab states, to be female and to be an athlete in Qatar is no longer as significant a cultural taboo as it once was.

\section{Local rivalries}

Qatar's persistent desire to emphasize a distinct identity from their GCC neighbours has taken a heightened significance since June 2017 when simmering tensions between the emirate and a Saudi-led bloc, including also Bahrain, Egypt and the UAE, escalated into a full land, sea and air blockade. It is an oversimplification to suggest that the World Cup was the sole reason for the worsening of relations between Qatar and its neighbours. ${ }^{37}$ However, there is little doubt that the potential for the prestige that the tournament will allow Qatar has contributed to the increase in tension between the rivalling factions. Qatar's relationship with Saudi Arabia has historically been a tempestuous one. Due in part to feudal claims by the House of Saud as well as the importance of transnational tribal ties in the Gulf, Qatar has been at times viewed as a pseudo-vassal state by its larger neighbour to the west. ${ }^{38}$ However in hosting the World Cup, as David Roberts states, the emirate 'is asserting both its right and also it legitimacy to act as a traditional state, a small point but nevertheless worth making against Qatar's backdrop of overarching Saudi power'. ${ }^{39}$ For many observers, the June 2017 blockade was an effort to force Qatar back into the thrall of Saudi hegemony, and on several occasions, relinquishing or at least sharing the 2022 World Cup has been mooted as a potential bargaining chip that could help lead to its resolution. ${ }^{40}$ Yet the return for Qatar in hosting the World Cup has the promise to be enormous in terms of establishing a national identity unique from its GCC neighbours. ${ }^{41}$ Not only will it place Doha on the global map in such a fashion that it threatens to overshadow the traditional capitals of the Middle East, it will also defy previous conceptions of the Arab world to present a society that is open, tolerant and progressive. In order to achieve this status, Qatar has made (and continues to make) changes that other Arab nations have not (or will not).

\section{The World Cup as cultural heritage}

As a nation becoming increasingly more estranged from its regional partners, both politically and it would appear to some extent in terms of its social practices, I argue that the World Cup becomes ever more important for Qatar. Evidenced by the ongoing changes related to the treatment of migrant workers and the evolution of women's sport in the country, it offers the opportunity to create a cultural heritage that will consolidate this unique identity. Drawing from the work of Jan Assmann and John Czaplicka, I suggest that the power of this cultural heritage has the potential to act as a mechanism for lasting change in Qatari society. According to Assmann and Czaplicka, engrained within the hosting of a World Cup is not just what the communal remembrance of an event, occurrence or incident. Also contained is the memory of the communal response to such an event, one that acts as 'a kind of identificatory determination in a positive ("We are this") or in a negative ("That's our opposite") sense'. ${ }^{42}$ More clearly, stated, such a memory also acts as a behavioural guide, one that dictates the appropriate action or response to any future reoccurrence of such a stimuli or event. It moves beyond the 'forming function' to the 'function of providing rules of conduct' that can shape future responses. ${ }^{43}$ The forthcoming World Cup I suggest is an example of such an event that is capable of generating a cultural heritage. It has prompted an unprecedented change in Qatari society. Issues relating to the kafala sponsorship system and women in sport that 
were significant up until the early part of the twenty-first century have experienced rapid change since it was announced that Qatar was to host the World Cup, and such changes are now becoming the norm in the Gulf state and will be extremely difficult to retract. Because of the transnational values and practices that Qatar has adopted in preparation for the tournament, there is the possibility of a lasting legacy beyond 2022 that may not have occurred.

The rationale for Qatar wanting to host the World Cup thus becomes somewhat more understandable. Its aims are multi-fold. Qatar wants to challenge the substance of the stereotypes associated with Arab society. It seeks to announce itself as a legitimate member of the global community, one whose values and social norms strongly resemble those practised in the liberal democracies of the West. It also aims to emphasize that while Qatar is part of a greater Arab and Muslim community, it also has its own specific national identity. While it is likely, given the Gulf state's incredible wealth, that a pro-active branding strategy and burgeoning political influence would allow Qatar to achieve these aims anyway in time, hosting the World Cup provides the opportunity to expedite this process dramatically.

\section{Qatar in the court of public opinion}

For the Gulf state however, hosting the World Cup was intended to be what Jonathan Grix and Donna Lee describe as a 'performative political practise' which would provide Qatar the opportunity to 'attract' other countries by projecting a carefully crafted international image of an openminded, modern society which was also both Muslim and Arab. ${ }^{44}$ Although Qatar won the voting process to host the 2022 World Cup, this was a process which occurred behind the closed doors of FIFA's political community. Upon being announced as the victor by FIFA however, Qatar's bid, its intricacies and the repercussions that would follow became firmly fixed in the court of public opinion. What has occurred since the announcement in Zurich was what Brannagan and Giulianotti have described as 'soft disempowerment'. ${ }^{45}$ According to Brannagan and Giulianotti, this can often occur when a nation seeks to create and disseminate a new image to a global audience and their social inequalities or failings are subsequently judged in the court of public opinion.

\section{Qatar and soft disempowerment}

Qatar's World Cup is perhaps one of the most stunning examples of how 'soft disempowerment', or public opinion, can work against a country as claims of corruption and unethical work practices mounted. ${ }^{46}$ The Ugly Game, written by Heidi Blake and Jonathan Calvert and published in 2015, goes to great lengths to disclose the efforts that took place in the years and months leading up to, as well as during, the voting stages of the bidding process for the 2022 World Cup. As Blake and Calvert repeatedly suggest in their text, the Qatari bid frequently went beyond the world of FIFA and its members to take advantage of the closeness between the Qatari government and the Bid Committee, to use state visits and capital investment projects to generate goodwill towards the emirate in the run-up towards World Cup voting process. These claims by Blake and Calvert would find traction in a multitude of other media. In addition to the suspicion raised by state visits to Vladimir Putin in Russia, journalists from a variety of outlets across the globe would allege that former French president Nicolas Sarkozy played an integral role in securing a vote for the Qatari bid from the then UEFA president, Michel Platini. Such accord was reached, according to Matt Spiro, by the emirate's agreement to invest heavily in the French domestic league and to rescue Paris SaintGermain, a club beleaguered at the time by financial woes. ${ }^{47}$ Concerns of a similar nature would also be raised as to how the Gulf state used its natural resources as a carrot to influence third parties to favour their bid. Reports in the Telegraph in 2014 alleged that a deal signed by QatarGas to supply Thailand with two million tonnes of liquefied natural gas had influenced the Thai Football Association's vote. ${ }^{48}$ Such claims would be repeated by Nick Harris in the Mail on Sunday asserted almost a year later with Paraguay allegedly the focus of Qatar's interest. ${ }^{49}$ 
Determining the truth as to whether Qatar used fair means or foul to win the hosting rights for the 2022 World Cup lays beyond the scope of this article. Both the Bid Committee and the Supreme Committee for Delivery and Legacy have always flatly denied any allegations of wrongdoing in their bid campaign, the most recent being accusations of a 'Black Ops' campaign to smear the American bid, insisting that they adhered to the stated FIFA Guidelines for the Bidding Process at all times. ${ }^{50}$ The Garcia Report finally published in 2017 did question the methods used by several of the bidding nations for the 2018 and 2022 World Cups. ${ }^{51}$ Yet, as noted by Marissa Payne in The Washington Post on the 27 June 2017, 'despite the salaciousness of some of the investigation's details, nothing in the report is so revelatory that would lead to either Russia or Qatar being stripped of the World Cup' ${ }^{52}$ All accusations made against Qatar have yet to be proven, but the allegations that the emirate used a combination of 'regional loyalties, football politics and alliances' to fulfil its goal of winning the right to host the World Cup continue to linger. ${ }^{53}$ The soft disempowerment brought about by such allegations has arguably seen the Gulf state lose as much as it has gained in terms of international prestige and credibility. Attempting to correct this imbalance was, and remains, a constant challenge for Qatar in its effort to make the nation's global image as attractive as possible. A central part of this process is the effort to use the World Cup to address these criticisms and demonstrate that unlike its regional partners, Qatar can coexist with the values and behavioural norms of the Cultural West.

\section{Conclusion}

As such, Qatar has come to realize since the announcement of its victory in Zurich almost a decade ago, this particular entrance onto the world stage does not come without its own pitfalls. FIFA's World Cup brings with it a uniquely transnational space, one that is intrinsically associated with the universal values of 'integrity, ethics and fair play' that FIFA insists the game of soccer is built on. ${ }^{54}$ Having won the rights to host the tournament, Qatar now has to ensure it is seen to be adhering to these values so that the national identity it seeks to project is accepted by the international community. This will not be an easy task given that in the aftermath of Russia 2018, Qatar is firmly under the microscope of public scrutiny. In awarding the latter the finals, FIFA has finally acknowledged a region that has long been neglected by global sport. In doing so, it is allowing Qatar the chance to assert an identity for both itself and the Arab world that is devoid of the Orientalism so often used to describe the region. The idea of a Middle Eastern World Cup, an Arab World Cup and a Muslim World Cup cements FIFA's aim to finally globalize the game of soccer and is truly historic. For its part however, Qatar has to demonstrate that the image it presents to the rest of the world as an open, tolerant and fair society is genuine. The reform of the kafala system, improved conditions for migrant workers and the increased participation of women in Qatari sport go some way to achieving this aim and create an equally historic legacy for both the Gulf state and the World Cup tournament itself. Although there is much row left to hoe, it does go some way to support the views of Hassan Al-Thawadi who has described the World Cup as 'an opportunity to be a catalyst for positive change' (New York Times, 9 October 2017). The challenge is to implement these changes without sacrificing what Matthew Gray describes its 'sense of "Qatari-ness"'. ${ }^{55}$ If it does so, the World Cup will not just be another significant moment in the history of soccer in the years to come. It will also have long-lasting social and cultural implications for the people of Qatar and their wish to declare a national identity to the world that is unique amidst a wider mosaic of Muslim and Arab identities.

\section{Notes}

1. Sugden and Tomlinson, 'Power and Resistance', 313.

2. There is significant overlap between the Qatari ruling family, the Qatari government, the country's sovereign wealth fund and the 2022 Bid Committee. As such, the term 'Qatar' used throughout the paper refers to the decision-making apparatus within Qatari society that is simultaneously the Emir and his immediate family, 
the government, the country's investment authority and the committee that actively promoted the emirate as a viable World Cup host from 2008 until 2010.

3. Amara, '2006 Qatar Asian Games'; 'The Muslim World'; and Sport, Politics and Society.

4. Brannagan and Giulianotti, 'Soft Power and Soft Disempowerment'; Reiche, 'Investing in Sporting Success'; Grix and Brannagan, 'Of Mechanisms and Myths'; and Henderson, 'Hosting the 2022 FIFA World Cup'.

5. Dorsey, 'The 2022 World Cup'; 'How Qatar Is Its Own Worst Enemy'; Dun, 'No Beer, No Way!'; Brannagan and Giulianotti, 'Soft Power and Soft Disempowerment'; and Brannagan and Rookwood, 'Sports Mega-events, Soft Power and Soft Disempowerment'.

6. Cornelissen, 'It's Africa's Turn!'; 'South Africa's "Coming out Party"'; Allison and Monnington, 'Sport, Prestige and International Relations'; Foley et al., 'Policy Pragmatism'; Grix and Houlihan, 'Sports MegaEvents'; Grix and Lee, 'Soft Power, Sports Mega-events'; Grix et al., 'Interrogating States' Soft Power Stragies'; Haut et al., 'International Prestige through Sporting Success'; and Dowse and Fletcher, 'Sporting MegaEvents'.

7. Fromherz, Qatar; Gray, Qatar; Kamrava, Qatar; Ulrichsen, Qatar and the Arab Spring; and Roberts, Qatar.

8. Roche, Mega-events and Modernity, 1.

9. Cornelissen, 'It's Africa's Turn', 1294.

10. Ibid., 1302.

11. Griffin, 'Football in the Hands of the Other'.

12. Said, Orientalism, 39.

13. Said, Culture and Imperialism, 67.

14. Griffin, 'Football in the Hands of the Other'. I argue that the purpose of negative portrayals of Qatar resides in the desire to control emerging ex-colonial nations, particularly those with newfound wealth and influence. They do so by attempting to re-assert the frameworks of power and dominance which have historically been to the benefit of the Cultural West.

15. Allison and Monnington, 'Sport, Prestige and International Relations', 5.

16. Amara, 'The Muslim World in the Global Sporting Arena', 69.

17. Said, Covering Islam, 10; and Kamrava, Qatar, xxi.

18. Amara, 'The Muslim World in the Global Sporting Arena', 73.

19. Brannagan and Giulianotti, 'Soft Power and Soft Disempowerment', 709.

20. Bromber and Krawietz ('The United Arab Emirates, Qatar, and Bahrain as a Modern Sport Hub') use Braudrillard's understanding of hyperreality to discuss the process of hosting first- and second-order sports events in the Gulf. They argue that hosting these sports does 'affirm their prestige in the world' (190), for Gulf nations such as Qatar, the UAE and Bahrain. However, they also claim that the resulting event is very often 'branded within a theme-park logic, [and] a rhetoric about lifestyle' (194) that signifies solely an aspired to sporting history and identity commodified for purposes of recognition and ingestion by the Cultural West.

21. Hall, 'Urban Entrepreneurship, Corporate Interests and Sports Mega-Events', 64.

22. Gray, Qatar, 228.

23. Ibid., 165.

24. Bhabha, Location of Culture, 37.

25. Sugden and Tomlinson, 'Power and Resistance', 312-13.

26. 'Qatar introduces minimum wage for first time'.

27. 'UN clears Qatar over treatment of migrant workers'; and Harwood, 'Qatar 2022 World Cup'.

28. 'ILO inaugurates its first project office in Qatar'.

29. Brannagan and Giulianotti, 'Soft Power and Soft Disempowerment', 708.

30. 'Hassan al-Thawadi on Worker Welfare'.

31. Knez et al., 'World Cup Football as a Catalyst for Change', 1757.

32. Ibid.

33. 'Qatar women's sports body'.

34. 'Education City Stadium'; 'HEY’YA: Arab Women in Sport'; and Ataullah, 'More Women Taking Part in Sports Events'.

35. 'Mariam wants to inspire young female athletes in Qatar'; Rehmat, 'Asian Games: Qatar to fight for medals'; and 'Women's football continues to develop in Qatar'.

36. Nayudu, 'Team Qatar athletes'.

37. Rumours and allegations that much of the 'bad press' that continues to appear relating to the 2022 World Cup is being disseminated by Saudi Arabian and Emirate sources raise a fascinating question about the Orientalization of the Other by the Other. Many of these stories emanate from several 'think thanks' based in the West whose funding is rumoured to be one of the aforementioned states. Foremost amongst these in recent times is the Foundation for Sports Integrity. Based in London and founded by Australian entrepreneur Jamie Fuller, they have led recent calls for Qatar to be stripped of the World Cup. Reports in the Guardian by Jim Waterson on 16 July 2018 suggest, however, that the foundation has been funded by Qatar's current rivals, Saudi Arabia and the UAE. This view is compounded by a subsequent piece by Waterson on 23 July 2018 of 
actors being paid by to protest a visit by the Emir of Qatar, Sheikh Tamim Bin Hamad Al Thani, to London. Allegations by all sides are denied.

38. Zahlan, Creation of Qatar, 80-85.

39. Roberts, Qatar, 121.

40. Harwood, 'Why FIFA's 48-team plan for the 2022 World'; and Rumsby, 'Qatar blockade will cease if nation surrenders 2022 World Cup'.

41. The overall cost of putting in place the necessary infrastructure to host the World Cup, in addition to building the necessary stadia, was estimated by various sources to be approximately $\$ 200$ billion, with the Guardian reporting in February 2017 that Qatar spending at that point had reached $\$ 500$ million per week. By comparison, the 2010 World Cup cost the South African government $\$ 3.5$ billion.

42. Assmann and Czaplicka, 'Collective Memory and Cultural Identity', 130

43. Ibid., 132.

44. Grix and Lee, 'Soft Power, Sports Mega-events and Emerging States', 526.

45. Brannagan and Giulianotti, 'Soft Power and Soft Disempowerment', 707.

46. Qatar's World Cup bid was not the first time its efforts were rebuffed by the international community. Bids launched in 2007 and 2011 to host the Olympic Games in 2016 and 2020 were both rejected due to a plethora of reasons. As per academic works on Qatar's social and cultural transformations by Nadine Scharfenort and Katrin Bromber, and a report by Roger Blitz in the Financial Times on 26 August 2011, these included excessive summer temperature, lack of tournament hosting experience, unscrupulous bidding tactics and a lack of a sporting heritage, specifically relating to female athletes. However, due to the unsuccessful nature of these bids, Qatar avoided much of the vitriol and scepticism that came with the announcement that it was to host the World Cup in 2022.

47. Spiros, 'Sarkozy Orchestrates Qatar's French Revolution'.

48. 'Qatar World Cup 2022'.

49. Harris, 'Qatar paid $£ 17.17$ billion'.

50. Merrill and Rumsby, 'Calls for Fifa to see evidence of Qatar'.

51. Garcia, Report on the Inquiry into the 2018/2022 FIFA World Cup, 339-42.

52. Payne, 'FIFA releases full "Garcia report"'; and Keh, 'In Long-Secret FIFA Report'.

53. Blake and Calvert, The Ugly Game, 40.

54. Fédération Internationale de Football Association, 'FIFA Statutes', 6.

55. Gray, Qatar, 228.

\section{Disclosure statement}

No potential conflict of interest was reported by the author.

\section{ORCID}

Thomas Ross Griffin (iD http://orcid.org/0000-0002-2279-2913

\section{Bibliography}

Allison, L., and T. Monnington. 'Sport, Prestige and International Relations'. in The Global Politics of Sport: The Role of Global Institutions in Sport, L. Allison. ed., 5-23. London: Routledge, 2009.

Amara, M. '2006 Qatar Asian Games: A “Modernization” Project from Above?'. Sport in Society 8, no. 3 (2005): 493-514. doi:10.1080/17430430500249217.

Amara, M. 'The Muslim World in the Global Sporting Arena'. The Brown Journal of World Affairs 14, no. 2 (2008): $67-75$.

Amara, M. Sport, Politics and Society in the Arab World. Palgrave MacMillan: Basingstoke, 2012.

Assmann, J., and J. Czaplicka. 'Collective Memory and Cultural Identity'. New German Critique 65 (1995): $125-133$. doi:10.2307/488538.

Ataullah, S. 'More Women Taking Part in Sports Events', The Peninsula, February 12, 2017.

Bhabha, H.K. The Location of Culture. London: Routledge, 1994.

Blake, H., and J. Calvert. The Ugly Game: The Corruption of FIFA and the Qatari Plot to Buy the World Cup. London: Simon \& Schuster, 2016.

Blitz, R. 'Qatar Joins Race for 2020 Olympics'. Financial Times, August 26, 2011. https://www.ft.com/content/ 2c192738-d008-11e0-81e2-00144feabdc0 
Brannagan, P.M., and R. Giulianotti. 'Qatar, Global Sport and the 2022 FIFA World Cup'. in Leveraging Legacies from Sports Mega- Events: Concepts and Cases, J. Grix. ed., 154-165. Basingstoke: Palgrave MacMillan, 2014.

Brannagan, P.M., and R. Giulianotti. 'Soft Power and Soft Disempowerment: Qatar, Global Sport and Football's 2022 World Cup Finals'. Leisure Studies 34, no. 6 (2015): 703-719. doi:10.1080/02614367.2014.964291.

Brannagan, P.M., and J. Rookwood. 'Sports Mega-events, Soft Power and Soft Disempowerment: International Supporters' Perspectives on Qatar's Acquisition of the 2022 FIFA World Cup Finals'. International Journal of Sport Policy and Politics 8, no. 2 (2016): 173-188. doi:10.1080/19406940.2016.1150868.

Bromber, K. 'The Sporting Way: Sport as Branding Strategy in the Gulf States'. In Under Construction: Logics of Urbanism in the Gulf Region, S. Wippel, K. Bromber, C. Steiner, and B. Krawietz. ed., 119-130. Farnham: Ashgate, 2014.

Bromber, K., and B. Krawietz. 'The United Arab Emirates, Qatar, and Bahrain as a Modern Sport Hub'. in Sport across Asia: Politics, Cultures and Identities, K. Bromber, B. Krawietz, and J. Maguire. ed., 189-211. London: Routledge, 2013.

Cornelissen, S. “'It's Africa's Turn!” The Narratives and Legitimations Surrounding the Moroccan and South African Bids for the 2006 and 2010 FIFA Finals'. Third World Quarterly 25, no. 7 (2004): 1293-1309. doi:10.1080/ 014365904200281285.

Cornelissen, S. 'South Africa's "Coming Out Party": Reflections on the Significance and Implications of the 2010 FIFA World Cup”. in Leveraging Legacies from Sports Mega- Events: Concepts and Cases, J. Grix. ed., $142-153$. Basingstoke: Palgrave MacMillan, 2014.

Dorsey, J. 'The 2022 World Cup: A Potential Monkey Wrench for Change'. The International Journal of the History of Sport 31, no. 14 (2014): 1739-1754. doi:10.1080/09523367.2014.929115.

Dorsey, J. 'How Qatar Is Its Own Worst Enemy'. The International Journal of the History of Sport 32, no. 3 (2015): 422-439. doi:10.1080/09523367.2015.1008212.

Dowse, S., and T. Fletcher. 'Sporting Mega-Events, the "Non-west” and the Ethics of Event Hosting'. Sport in Society: Culture, Commerce, Media, Politics 21, no. 5 (2018): 745-761. doi:10.1080/17430437.2018.1401359.

Dun, S. 'No Beer, No Way! Football Fan Identity Enactment Won't Mix with Muslim Beliefs in the Qatar 2022 World Cup'. Journal of Policy Research in Tourism, Leisure and Events 6, no. 2 (2014): 186-199. doi:10.1080/ 19407963.2014.925256.

Education City Stadium. 'Supreme Committee for Delivery and Legacy'. 2018. https://www.sc.qa/en/stadiums/ education-city-stadium

Fédération Internationale de Football Association. 'FIFA Statutes: Regulations Governing the Application of the Statutes'. August 2018 ed, 2018. https://resources.fifa.com/image/upload/the-fifa-statutes-2018.pdf?cloudid= whhncbdzio03cuhmwfxa

Foley, M., D. McGillivray, and G. McPherson. 'Policy Pragmatism: Qatar and the Global Events Circuit'. International Journal of Event and Festival Management 3, no. 1 (2012): 101-115. doi:10.1108/ 17582951211210960.

France-Presse, A. 'Qatar Spending \$500m a Week on World Cup Projects’. Guardian, February 8, 2017. https://www. theguardian.com/football/2017/feb/08/qatar-spending-500m-a-week- on-world-cup-projects-2022

Fromherz, A. Qatar: A Modern History. London: I.B. Taurus, 2012.

Garcia, M.J. Report on the Inquiry into the 2018/2022 FIFA World Cup Bidding Process. Zurich: NP, 2014. https:// resources.fifa.com/mm/document/affederation/footballgovernance/02/89/87/97/aus_bel-ned_eng_esppor_jpn_kor_qat_report_neutral.pdf.

Gray, M. Qatar: Politics and the Challenges of Development. Boulder, CO: Lynne Rienner, 2013.

Griffin, R. 'Football in the Hands of the Other: Qatar's World Cup in the British Broadsheet Press'. Arab World Geographer 20, no. 2-3 (2017): 170-182. http://arabworldgeographer.org/doi/abs/10.5555/1480-6800.20.2.170? code=AWGP-site.

Grix, J., and P.M. Brannagan. 'Of Mechanisms and Myths: Conceptualising States' "Soft Power" Strategies through Sports Mega-Events'. Diplomacy \& Statecraft 27, no. 2 (2016): 251-272. doi:10.1080/09592296.2016.1169791.

Grix, J., P.M. Brannagan, and B. Houlihan. 'Interrogating States' Soft Power Strategies: A Case Study of Sports Megaevents in Brazil and the UK'. Global Society 29, no. 3 (2015): 463-479. doi:10.1080/13600826.2015.1047743.

Grix, J., and B. Houlihan. 'Sports Mega-Events as Part of a Nation's Soft Power Strategy: The Cases of Germany (2006) and the UK (2012)'. The British Journal of Politics and International Relations 16, no. 4 (2013): 572-596. doi:10.1111/1467-856X.12017.

Grix, J., and D. Lee. 'Soft Power, Sports Mega-events and Emerging States: The Lure of the Politics of Attraction'. Global Society 27, no. 4 (2013): 521-536. doi:10.1080/13600826.2013.827632.

Hall, C.M. 'Urban Entrepreneurship, Corporate Interests and Sports Mega-Events: The Thin Policies of Competitiveness within the Hard Outcomes of Neoliberalism'. Sociological Review 54 (2006): 59-70. doi:10.1111/j.1467-954X.2006.00653.

Harris, N. 'Qatar Paid £17.17billion to Host the 2022 World Cup Finals, and New Research Shows Where All That Money Went'. Mail on Sunday, April 25, 2015. http://www.dailymail.co.uk/sport/football/article-3055550/Qatarpaid-17-17billion-host-2022-World-Cup-finals-new-research-shows-money-went.html 
Harwood, A. 'Qatar 2022 World Cup Will Honour Workers' Rights with the End of the Kafala System, Predicts ITUC Head'. Independent, January 28, 2018. https://www.independent.co.uk/sport/football/international/qatar-2022world-cup-workers-rights-kafala-system-migraints-middle-east-a8182191.html

Harwood, A. 'Why FIFA's 48-team Plan for the 2022 World Cup Is Bad News for Qatar'. Independent, April 13, 2018. https://www.independent.co.uk/sport/football/international/world-cup-2022-qatar-48-teams-fifa-bad-newssaudi-arabia-kuwait-iran-a8303706.html

'Hassan al-Thawadi on Worker Welfare, Qatari Goals and the 2022 World Cup'. New York Times, October 9, 2017. https://www.nytimes.com/2017/10/09/sports/soccer/world-cup-qatar-2022-al-thawadi.html

Haut, J., J. Grix, P.M. Brannagan, and I. van Hilvoorde. 'International Prestige through Sporting Success: An Evaluation of the Evidence'. European Journal for Sport and Society 14, no. 4 (2017): 311-326. doi:10.1080/ 16138171.2017.1421502.

Henderson, J. 'Hosting the 2022 FIFA World Cup: Opportunities and Challenges for Qatar'. Journal of Sport \& Tourism 19, no. 3-4 (2014): 281-298. doi:10.1080/14775085.2015.1133316.

HEY'YA: Arab Women in Sport. Qatar Museums. http://www.qm.org.qa/en/project/heyya-arab-women-sport

ILO inaugurates its first project office in Qatar. 'International Labour Organization'. April 30, 2018. https://www.ilo. org/beirut/media-centre/news/WCMS_627158/lang-en/index.htm

Kamrava, M. Qatar: Small State, Big Politics. Ithaca: Cornell University Press, 2013.

Keh, A. 'In Long-Secret FIFA Report, More Details but No Smoking Gun'. New York Times, June 27, 2017. https://www. nytimes.com/2017/06/27/sports/fifa-garcia-report.html

Knez, K., T. Benn, and S. Alkhaldi. 'World Cup Football as a Catalyst for Change: Exploring the Lives of Women in Qatar's First National Football Team - A Case Study'. The International Journal of the History of Sport 31, no. 14 (2014): 1755-1773. doi:10.1080/09523367.2014.935935.

Mariam Wants to Inspire Young Female Athletes in Qatar. DohaStadiumPlus.com, April 27, 2017. http://www. dohastadiumplusqatar.com/contentpage.aspx?article=Mariam-wants-to-inspire-young-female-athletes-in-Qatar-

Merrill, J., and B. Rumsby. 'Calls for Fifa to See Evidence of Qatar “Sabotage” over 2022 World Cup Bid'. Telegraph, July 29, 2018. https://www.telegraph.co.uk/football/2018/07/29/calls-fifa-see-evidence-qatar-sabotage-2022-world-cup-bid/

Nayudu, V. 'Team Qatar Athletes Aim for a Top Show at Asian Games in Indonesia'. Qatar Tribune, May 30, 2018. http://www.qatar-tribune.com/news-details/id/126977

Payne, M. 'FIFA Releases Full "garcia Report”, Outlining Further Corruption but No Smoking Gun in World Cup Bids'. Washington Post, June 2017. https://www.washingtonpost.com/news/early-lead/wp/2017/06/27/fifa-releases -full-garcia-report-outlining-further-corruption-but-no-smoking-gun-in-world-cup-bids/?noredirect=on\&utm term $=.6 \mathrm{f} 4 \mathrm{~b} 2 \mathrm{acbec} 0 \mathrm{~d}$

Qatar introduces minimum wage for first time. BBC. October 25, 2017. https://www.bbc.com/news/world-middleeast-41752490

Qatar women's sports body honours Bayern women's team. Qatar Tribune. February 1, 2018. http://www.qatartribune.com/news-details/id/126977

'Qatar World Cup 2022: The Thai Gas Deal Struck Shortly before the Vote'. Telegraph. June 3, 2014. https://www. telegraph.co.uk/sport/football/world-cup/10871555/Qatar-World-Cup-2022-the-Thai-gas-deal-struck-shortlybefore-the-vote.html

Rehmat, R. '2018 Asian Games: Qatar to Fight for Medals in Indonesia'. The Peninsula, March 8, 2018. https://www. thepeninsulaqatar.com/article/08/03/2018/2018-Asian-Games-Qatar-to-fight-for-medals-in-Indonesia

Reiche, D. 'Investing in Sporting Success as a Domestic and Foreign Policy Tool: The Case of Qatar'. International Journal of Sport Policy and Politics 7, no. 4 (2014): 489-504. doi:10.1080/19406940.2014.966135.

Roberts, D. Qatar: Securing the Global Ambitions of a City-state. London: Hurst, 2017.

Roche, M. Mega-Events and Modernity: Olympics and EXPOS in the Growth of Global Culture. London: Routledge, 2002.

Rumsby, B. 'Qatar Blockade Will Cease if Nation Surrenders 2022 World Cup, Says Dubai Official'. Telegraph, October 9, 2017. https://www.telegraph.co.uk/football/2017/10/09/qatar-blockade-will-cease-nation-surrenders -2022-world-cup-says/

Said, E. Covering Islam: How the Media and the Experts Determine How We See the Rest of the World. London: Vintage, 1994.

Said, E. Culture and Imperialism. London: Vintage, 1994.

Said, E. Orientalism. London: Penguin, 2003.

Scharfenort, N. 'Urban Development and Social Change in Qatar: The Qatar National Vision 2030 and the 2022 FIFA World Cup'. Journal of Arabian Studies: Arabia, the Gulf, and the Red Sea 2, no. 2 (2012): 209-230. doi:10.1080/ 21534764.2012.736204.

Silva, L. 'The Establishment of the Qatar National Olympic Committee: Building the National Sport Identity'. The International Journal of the History of Sport 31, no. 3 (2014): 306-319. doi:10.1080/09523367.2013.878136.

Spiro, M. 'Sarkozy Orchestrates Qatar's French Revolution'. Irish Times, November 19, 2011. https://www.irishtimes. com/sport/sarkozy-orchestrates-qatar-s-french-revolution-1.13902 
Sugden, J., and A. Tomlinson. 'Power and Resistance in the Governing of World Football: Theorizing FIFA's Transnational Impact'. Journal of Sport \& Social Issues 22, no. 3 (1998): 299-316. doi:10.1177/ 019372398022003005.

Ulrichsen, K. Qatar and the Arab Spring. Oxford: Oxford University Press, 2014.

UN clears Qatar over treatment of migrant workers. 'Al Jazeera'. November 8, 2017. https://www.aljazeera.com/ news/2017/11/clears-qatar-treatment-migrant-workers-171108145003698.html

Waterson, J. 'Football and Fat Fees: Questions Raised over Funding of Sporting Conference'. Guardian, July 16, 2018. https:/www.theguardian.com/football/2018/jul/16/football-and-fat-fees-questions-raised-over-funding-ofsporting-conference

Women's football continues to develop in Qatar. 'Evolution Sports Qatar'. November 6, 2017. http://www.evosports qatar.com/press-evo/956-women-s-football-continues-to-develop-in-qatar

Zahlan, R. The Creation of Qatar. London: Croom Helm, 1979. 